COLONIAL VIRGINIA'S PAPER MONEY REGIME, 1755-1774:

VALUE DECOMPOSITION AND PERFORMANCE

\author{
Farley Grubb \\ Working Paper 21881 \\ http://www.nber.org/papers/w21881 \\ NATIONAL BUREAU OF ECONOMIC RESEARCH \\ 1050 Massachusetts Avenue \\ Cambridge, MA 02138 \\ January 2016
}

The views expressed herein are those of the author and do not necessarily reflect the views of the National Bureau of Economic Research.

NBER working papers are circulated for discussion and comment purposes. They have not been peer-reviewed or been subject to the review by the NBER Board of Directors that accompanies official NBER publications.

(C) 2016 by Farley Grubb. All rights reserved. Short sections of text, not to exceed two paragraphs, may be quoted without explicit permission provided that full credit, including () notice, is given to the source. 
Colonial Virginia's Paper Money Regime, 1755-1774: Value Decomposition and Performance Farley Grubb

NBER Working Paper No. 21881

January 2016, Revised March 2016

JEL No. E42,E51,G12,H60,N12,N22

\begin{abstract}
$\underline{\text { ABSTRACT }}$
I decompose Virginia's paper money into expected real-asset present value, risk discount, and transaction premium or "moneyness" value. The value of Virginia's paper money was determined primarily by its real-asset present value. The transaction premium was small. Positive risk discounts occurred in years when treasurer malfeasance was suspected. Virginia's paper money was not a fiat currency, but a barter asset, with just enough "moneyness" value to make it the preferred medium of exchange for local transactions. Compared with alternative models, my decomposition model of inside monies is superior conceptually and statistically for explaining the performance of American colonial paper monies.
\end{abstract}

\author{
Farley Grubb \\ University of Delaware \\ Economics Department \\ Newark, DE 19716 \\ and NBER \\ grubbf@udel.edu
}




\title{
Colonial Virginia’s Paper Money Regime, 1755-1774: Value Decomposition and Performance
}

\author{
Farley Grubb ${ }^{1}$
}

I decompose Virginia’s paper money into expected real-asset present value, risk discount, and transaction premium or "moneyness" value. The value of Virginia's paper money was determined primarily by its real-asset present value. The transaction premium was small. Positive risk discounts occurred in years when treasurer malfeasance was suspected. Virginia's paper money was not a fiat currency, but a barter asset, with just enough "moneyness" value to make it the preferred medium of exchange for local transactions. Compared with alternative models, my decomposition model of inside monies is superior conceptually and statistically for explaining the performance of American colonial paper monies.

In 1755, Virginia and Georgia became the last of the 13 colonies to emit paper money.

The performance of Virginia's paper money regime is central to the history of the period; it was

at the center of the conflict with the Crown over colonial monetary powers and provided

Parliament justification for passing the Currency Act of 1764 (4 Geo III c. 34). This conflict

contributed to revolutionary sentiments. Virginia’s paper money regime was also a contentious

point in Virginia politics. Irregular activities by Virginia’s treasurer occupied a substantial

amount of political attention. Virginia's administrative structure was altered as a result. ${ }^{2}$

I model and statistically evaluate Virginia’s paper money regime. Such has not been done before. I apply my decomposition model for inside monies to Virginia’s paper money to track the determinants of the paper money’s value over time (Celia and Grubb 2016; Grubb 2014, 2016). I measure whether and to what extent this paper money functioned as “money” as opposed to just being a barter asset. I establish the timing and estimate the magnitude of the risk attached to this money when monetary troubles were suspected. I also construct the quantitative monetary data

\footnotetext{
${ }^{1}$ Professor and NBER Research Associate, Economics Department, University of Delaware, Newark, DE 19716. Email: grubbf@udel.edu. Web-page: http://www.lerner.udel.edu/faculty-staff/faculty/farley-grubb. A preliminary version was presented at Vanderbilt University, Oct. 2015. The author thanks the participants for helpful comments. Research assistance by Changqing $\mathrm{Mu}$ and editorial assistance by Tracy McQueen are gratefully acknowledged.

${ }^{2}$ Brock (1975, pp. 465-527); Ernst (1973); Greene and Jellison (1961); Journal of the Commissioners for Trade and Plantations from January 1759 to December 1763 (1970, pp. 330-5); Labaree (1966, v. 9, pp. 131-53); Mays (1952, v. 1, pp. 174-208, 358-85).
} 
needed to execute this approach (Grubb 2015).

Paper money was created by the Virginia legislature and directly spent by that legislature through its treasury. Legislature-issued, colony-specific paper monies were the only paper monies in circulation in colonial America. No public or private incorporated banks issuing paper banknotes backed by fractional specie reserves, with said banknotes redeemable at face value in specie at the issuing bank, existed in colonial America (Hammond 1991, pp. 3-67).

Prior to emitting paper money, Virginia's media of exchange consisted of barter, typically involving book credit transactions and tobacco—often in the form of claims to tobacco or tobacco notes; personal bills of exchange and promissory notes; and foreign specie coins (Breen 1985, pp. 94-7; Tillson 2010, pp. 36-8, 64). The composition of this media is unknown, though specie coins were considered relatively scarce. Virginia referred to its paper money as treasury notes. Other colonies referred to their paper monies as bills of credit. While treasury notes were the same as bills of credit, I will refer to Virginia's paper money as notes rather than bills in keeping with Virginia's terminology (Hening 1969, v. 7, p. 353).

The paper proceeds as follows: First, I discuss the institutional structure of Virginia's paper money regime, how the mechanics of paper money emissions and redemptions worked, and report the forensically reconstructed data needed to statistically analyze regime performance. Second, I present my decomposition model of monetary performance and apply that model to the data. Third, I statistically evaluate that model using the data. I also compare it with the statistical outcome of the most prominent, and only other, alternative model of colonial paper money performance that can be estimated. I conclude with a summary of the findings.

\section{Institutional Structure and Quantitative Measures}

Virginia had the second largest free population of the 13 colonies (Carter, et al. 2006, v. 
5, p. 652). Why Virginia took so long to initiate its own paper money regime is curious. Budgetary crises caused by wars typically pushed colonies into a paper money system (Grubb 2016). Virginia did not face such a crisis until the Seven Year's War. The immediate and large spending demands of Virginia's participation in that war swamped Virginia's ability to raise enough taxes immediately to meet these expenses (Brock 1975, pp. 466-9, 476).

Colonial governments faced standard budget constraints. Tax receipts had to match spending; when they didn't, colonial governments had to adjust their borrowing and asset positions. Colonial governments did not have asset positions, such as stocks of gold and land. External markets where colonial governments could borrow were not adequately developed or accessible (Brock 1975, pp. 467-9). Thus, when current tax receipts did not match current spending, colonial governments had to move tax receipts through time to balance budgets.

Virginia did this by issuing treasury notes as a paper money (M), see equation (1). Paper money creation was a credit-debt mechanism that matched budget deficits with budget surplus over a multi-year horizon. The balanced budget requirement was cut loose from a strict time unit, such as the fiscal year. It still had to be balanced, but now it could be balanced over a multi-year horizon. Colonial paper money acts included concurrent tax legislation designed to redeem the notes emitted at their face value in the near future. Redeemed notes would be removed from circulation and subsequently destroyed.

$$
0<\left(G_{j}-T_{j}\right)=M_{j} \leq \sum_{t=j+1}^{N}\left(T_{t}-G_{t}\right)>0
$$

$\mathrm{M}_{\mathrm{j}} \quad$ = new emissions of $\mathrm{M}$ (treasury notes) in year $\mathrm{j}$

$\mathrm{T}=$ taxes

$\mathrm{G} \quad$ = government spending

To maintain fiscal credibility, future taxes in excess of spending, $\left(T_{t}-G_{t}\right)>0$, had to be 
spread over numerous years, especially when $\mathrm{M}_{\mathrm{j}}$ was large. This process allowed a colony to marshal more resources to throw immediately into battle than what could be done by relying only on current tax receipts. For example, Virginia's paper money acts passed during the Seven Year's War (1755-62) stated:

And whereas, by reason of the long time allowed for collecting the duties imposed by this act, (Which, from the distressed circumstances of the people, and the great scarcity of gold and silver coin in this colony, could not be sooner done) the said duties will not be collected in time to answer the purposes [funding troops] hereby intended, Be it therefore enacted, That John Robinson,...treasurer of this colony,... is hereby authorized, and required to issue and emit so many treasury notes, as will be sufficient for the purposes aforesaid,...(from the March 1756 act, Hening 1969, v. 7, p. 32, italics in original)

This process imparted a time-discounting dimension to the notes emitted. After 1756, Virginia's notes paid no interest. They were, in effect, zero-coupon bonds.

The typical method of tax-redemption was to set net new taxes to redeem $\mathrm{M}_{\mathrm{j}}$ to be an equal amount per year $\left(F_{t}\right)$ over an N-year redemption window, i.e. $\left(T_{t}-G_{t}\right) / N=F_{t}$ for years $j+1$ through N. The Virginia legislature took note redemption and its effect on controlling the value of its paper money seriously. Such is illustrated in the March 1760 paper money act which stated,

And whereas it is of the greatest importance to preserve the credit of the paper currency of this colony, and nothing can contribute more to that end than a due care to satisfy the publick that the paper bills of credit, or treasury-notes, are properly sunk, according to the true intent and meaning of the several acts of assembly passed for emitting the same; and the establishing a regular method for this purpose may prevent difficulties and confusion in settling the publick accounts,... Be it therefore enacted, by the authority aforesaid, That Peyton Randolph, esquire, Robert Carter Nicholas, Benjamin Waller, Lewis Burwell and George Wythe, gentleman, or any three of them, be, and they are hereby appointed a committee, to examine at least twice in every year (and oftener, if thereto desired by the treasurer for the time being) all such bills of credit, or treasury-notes, redeemable on the first day of March, one thousand seven hundred and sixty five, as have been or shall be paid into the treasury, in discharge of the duties and taxes imposed by any former act of assembly; and upon receipt of the said bills or notes, the said committee shall give to the treasurer for the time being a certificate of the amount thereof, which shall avail the said treasurer in the settlements of his accounts...: And the said committee are hereby required and directed, so soon as they have given such certificate, to cause all such bills or notes to be burnt and destroyed. (Hening 1969, v. 7, p. 353, italics in the original) 
If taxes were paid in $\mathrm{M}$, then using the $\mathrm{F}_{\mathrm{t}}$ method removed $\mathrm{M}_{\mathrm{j}}$ from circulation at a constant amount over the $\mathrm{N}$-year redemption window. If taxes were paid by other means, such as in specie coins, then $\mathrm{M}_{\mathrm{j}}$ would continue in circulation until year $\mathrm{N}$ when it would be redeemed at face value and removed from circulation using the accumulated non-note tax receipts in the treasury. The language in the 1756 paper money acts illustrates this redemption structure.

That all such notes, so issued, shall be redeemable on the last day of June one thousand seven hundred and sixty, and shall then be paid by the treasurer... That the several sums of money and tobacco to be collected, by virtue of this act,.... shall be,...paid to John Robinson, esquire, treasurer of this colony,... That the money to be raised by the duties imposed by this act, shall stand, be, and remain as a security for the redemption of the said treasury notes so to be issued, and the said John Robinson, treasurer,... is hereby required to apply all such money, as shall come to his hands, by virtue of this act, for, and toward the redemption of such treasury notes, and to no other use or purpose whatsoever. (Hening 1969, v. 7, pp. 19, 29, 32).

All of Virginia’s paper money acts had this language. By “money,” colonists typically meant specie monies, sometimes referred to as real money. The face value of the notes for redemption purposes was fixed in law to be $1 £_{\mathrm{VA}}=200$ pounds of tobacco $=1.25 £_{\mathrm{S}}\left[£_{\mathrm{VA}}=\right.$ Virginia paper pounds, $£_{S}=$ pounds sterling] (Hening 1969, v. 6, pp. 468-9, 568-9; v. 7, pp. 9-10, 28-9).

\section{a. Virginia’s Paper Money Acts}

Table 1 compiles the paper money acts passed by the Virginia legislature and lists the key features of each act. Fifteen separate paper money acts that involved net new emissions were passed, with a cumulative total of 484,963£ $£_{\mathrm{VA}}$ in net new emissions made between 1755 and 1774. Notes issued under different acts could be distinguished by the acts' emission dates printed on the notes (Newman 2008, pp. 437-57).

Paper money acts began with statements about why monies were required, and in what amounts. Thirteen of the 15 acts stated that the money was required to cover military expenses. Paying for military expenses represented 90 percent of all net new paper monies emitted, and 98 
how the money would be raised. Regarding spending, these particulars involved such things as military recruitment, fortification construction, and how tobacco losses would be assessed. Regarding how money would be raised, these particulars established the type of taxes, the tax rates, and the taxing period to be used to raise the money required by the act.

Every paper money act listed a single date after which the act's notes could be redeemed at the treasury, see Table 1 . Redemption was at face value. In each paper money act, the redemption date and the end of the taxing period imposed to raise the money required by that act are a close match. In each act, taxing and redemption are clearly linked. Per act, the amounts of taxes imposed were expected to generate the sums needed to redeem all the notes emitted.

Every paper money acts stated the penalty for counterfeiting and contained a statement about legal tender status of the notes emitted. The first five emissions were made a "soft" legal tender. Citizens could be penalized for not accepting the paper money in trade, but the acts did not impose a value at which citizens had to accept the notes. Emissions \#6 through \#13 were made a "hard" legal tender. Citizens could be penalized not only for not accepting the paper money in trade, but also for not accepting paper money at its specie-equivalent face value.

With the passage of the 1764 Currency Act, emissions \#14 and \#15 could not be made a comprehensive legal tender. The legal tender language in these last two acts made the paper money emitted a legal tender for payments by the treasurer to discharge all legal demands brought against Virginia and a legal tender for paper money redemption purposes. However, the paper money passed current in the colony only between persons willing to so receive such notes in payment. Grubb (2016) shows why legal tender laws had little effect on note value.

Table 1 also identifies three rule changes that altered prior paper money acts. Emission \#6 included a clause that required all outstanding notes of emissions \#2, \#3, and \#4, along with 
their accrued interest to that point, to be swapped for emission \#6 notes. This swap removed any future interest payments attached to these prior emissions and altered the redemption dates of these prior emissions to that of emission \#6 notes. On 3 November 1761, the legislature changed the redemption date for all notes currently in circulation, lengthening the redemption period to 20 October 1769. This rule change, however, was passed with a suspending clause, and the Board of Trade laid it aside (suspended it) on 4 February 1763 (Hening 1969, v. 7. p. 466; Journal of the Commissioners for Trade and Plantations from January 1759 to December 1763, 1970, pp. 3334). Finally, the legislature on 4 March 1773 replaced the notes still outstanding from emissions \#14 and \#15 with new notes and changed their redemption date to 1 June 1774 . This note swap was intended to thwart counterfeiters.

All three rule changes did two things. Notes currently in circulation from different emissions with different final redemption dates had different present values. Such differences made for a cumbersome medium of change. The rule changes made all notes currently in circulation have the same expected present value by giving them the same final redemption date. The legislature gave the following reason for these rules changes, “...it will be prejudicial to have notes of different value circulating at the same time...” (Hening 1969, v. 7, p. 81) All three rule changes, however, were also an ex post facto altering of the expected present value of the notes affected, in most cases reducing that present value from what it was under the original act. The ex post facto reduction of the present value of notes in the 1761 rule change was an important factor leading to that rule change being suspended by the Board of Trade.

\section{b. Forensic Reconstruction of Virginia's Paper Money Flows}

Evaluating the performance of Virginia's paper money requires knowing the amount of notes in public circulation each year and the amount of notes redeemed (removed) from the 
public each year. Unfortunately, the treasury accounts that have survived, as reported in the Journals of the House of Burgesses, are irregular and inconsistent in their organization, timing of reporting, completeness, and in how they use such terms as notes "in circulation” and notes “issued.” 3 An extensive forensic accounting exercise is required to sort this material out. This involves paying close attention to internal consistency and coherence across accounts, in the language used, and with the statutory acts. Some controlled back-projection, interpolation, and data cloning are also required. Grubb (2015) provides the details of this forensic accounting reconstruction of the data. The outcome is reported in Table 2.

Column (1) in Table 2 incorporates three adjustments to the amounts authorized by statutory law. First, one-for-one currency swaps are netted out. Second, amounts never released from the treasury and subsequently burned without ever being emitted are netted out. Lastly, notes not emitted when authorized, but held in the treasury and emitted to the public in a later year, are moved to the year when emitted.

Column (2) in Table 2 incorporates three adjustments. First, notes burned that were not redeemed from the public or were burned as part of a one-for-one currency swap are netted out. Second, the timing of when notes were removed from circulation is adjusted such that notes listed as burned in the early months of a given year are counted as being removed from public circulation in the immediately prior year. Typically, taxes were collected in the fall. The account of notes burned from these taxes, however, was not reported until the following spring. Third, some notes paid into the treasury as taxes sat idle there for a number of years before being burned. When these notes were actually removed from public circulation is estimated by cloning the expected tax revenue stated for 1763 into expected tax revenues for other years. When notes

\footnotetext{
${ }^{3}$ Kennedy (1906a, pp. xi-xxv, 64-6, 108, 118-20, 124-8, 154-6, 283-5, 303; 1906b, pp. 72, 217-8; 1907, pp. 143, 171, 176-8, 356-7); McIlwaine (1908, pp. 15, 36-7, 115-6, 171-2, 249-50; 1909, pp. 388, 458, 487-90).
} 
Table 2 Forensic Reconstruction of Virginia’s Paper Money Regime, 1755-1775

\begin{tabular}{|c|c|c|c|c|}
\hline Year & $\begin{array}{l}\qquad(1) \\
\text { Net New } \\
\text { Notes } \\
\text { Emitted to } \\
\text { the Public } \\
\text { Each Year }\end{array}$ & $\begin{array}{l}\quad(2) \\
\text { Notes } \\
\text { Redeemed } \\
\text { from the } \\
\text { Public } \\
\text { Each Year }\end{array}$ & $\begin{array}{l}\quad(3) \\
\text { Resulting } \\
\text { Notes } \\
\text { in Public } \\
\text { Circulation } \\
\quad\left(\mathrm{M}_{\mathrm{t}}\right)\end{array}$ & $\begin{array}{l}\qquad(4) \\
\text { Accumulated Non-Note Tax } \\
\text { Redemption Revenues in the } \\
\text { Treasury Earmarked to Redeem } \\
\text { Notes at their Final Legislated } \\
\text { Redemption Date }\end{array}$ \\
\hline & $£_{\mathrm{VA}}$ & $£_{\mathrm{VA}}$ & $\varepsilon_{\mathrm{VA}}$ & $£_{\mathrm{VA}}$ \\
\hline 1755 & 37,179 & 0 & 37,179 & 1,860 \\
\hline 1756 & 74,336 & 15,932 & 95,583 & 8,688 \\
\hline 1757 & 85,753 & 13,731 & 167,605 & 12,742 \\
\hline 1758 & 81,831 & 26,118 & 223,318 & 20,453 \\
\hline 1759 & 69,749 & 26,118 & 266,949 & 28,164 \\
\hline 1760 & 53,999 & 24,682 & 296,266 & 35,451 \\
\hline 1761 & 5,244 & 28,003 & 273,507 & 43,718 \\
\hline 1762 & 19,782 & 28,003 & 265,286 & 51,985 \\
\hline 1763 & 10,627 & 22,793 & 253,120 & 65,462 \\
\hline 1764 & 2,502 & 26,300 & 229,322 & 81,012 \\
\hline 1765 & 0 & 16,949 & 212,373 & 91,033 \\
\hline 1766 & 0 & 19,148 & 193,225 & $98,855^{\mathrm{a}}$ \\
\hline 1767 & 0 & 25,751 & 167,474 & 10,519 \\
\hline 1768 & 0 & 25,751 & 141,723 & 21,039 \\
\hline 1769 & 10,000 & 21,046 & 130,677 & 29,636 \\
\hline 1770 & 0 & 10,541 & 120,136 & 8,561 \\
\hline 1771 & 30,000 & 10,944 & 139,192 & 16,712 \\
\hline 1772 & 0 & 36,562 & 102,630 & 7,366 \\
\hline 1773 & 0 & 36,562 & 66,068 & 5,554 \\
\hline 1774 & 0 & 23,355 & 42,713 & 3,742 \\
\hline 1775 & $0^{\mathrm{b}}$ & 2,763 & 39,950 & 1,930 \\
\hline Totals & 481,002 & 441,052 & & \\
\hline
\end{tabular}

Source: Table 1; Grubb (2015); Kennedy (1906a, pp. xi-xxv, 64-6, 108, 118-20, 124-8, 154-6, 283-5, 303; 1906b, pp. 72, 217-8; 1907, pp. 143, 171, 176-8, 356-7); McIlwaine (1908, pp. 15, 36-7, 115-6, 171-2, 249-50; 1909, pp. 388, 458, 487-90); William and Mary College Quarterly Historical Magazine (1912, pp. 227-62).

${ }^{\mathrm{a}}$ The accumulated non-note revenues to 1766 are assumed to be the sums removed from the treasury by John Robinson, treasurer over this period, which he loaned to his friends. Robinson died 11 May 1766. His estate was required to pay these amounts back to the treasury. This happened slowly over the next decade. Of the amounts Robinson removed from the treasury were $95,828 £_{\mathrm{VA}}$ of accumulated taxes held for redemption of notes when said notes' circulation time was at an end. In 1766, it was recorded that only $2,218 £_{\mathrm{VA}}$ was left in the treasury to pass on to the new treasurer after Robinson death (to use for note redemption). The closeness of the $95,828 £_{\mathrm{VA}}$ figure with what would have accumulated in the treasury into 1766 , namely $\left(98,855 £_{\mathrm{VA}}-2,218 £_{\mathrm{VA}}\right)=96,637 £_{\mathrm{VA}}$, provides support for the data construction used here. See Grubb (2015).

bxcludes net new emissions late in 1775. See Newman (2008, pp. 444-6).

were actually removed from the public is prorated by these expected yearly tax revenues. The 
numbers in column (3) of Table 2 for year $t$ is the number in column (1) for year $t-1$, plus the number in column (1) in year $t$, minus the number in column (2) in year $t$.

Finally, column (4) of Table 2 estimates the accumulated amount of non-note tax revenues, primarily specie coins, in the treasury that was to be used to redeem notes at their final legislated redemption date. These amounts are needed, along with the amounts in column (2), to estimate the real-asset present value of notes. In addition, adjustments to these amounts need to be incorporated. For example, John Robinson, the treasurer, removed the amount that had accumulated into 1766 by loaning these sums out to friends. This action was considered irregular and possible malfeasance. It created a scandal and the possibility that notes could not be redeemed when they came due at the treasury. Suspicions that such was going on affected the expected real-asset present value of the notes in the years prior to 1766.

When notes became redeemable at the treasury for the tax monies accumulated, they were not always immediately redeemed. The monies held in the treasury for their redemption continued to be held for that purpose. These notes continued in circulation and, at this point, took on a redeemable-upon-demand quality with 100 percent reserve-backing in the treasury. Such behavior needs to be incorporated into calculating the real-asset present values of the notes.

For example, emission \#5 was redeemable at the treasury at the end of 1757, but was not all redeemed until 1766. The tax monies received in 1757 for its redemption continued to be held in the treasury for future redemption of emission \#5 notes (Grubb 2015). Robert Carter Nicholas, treasurer after 1766, observed similar behavior. In 1773, he noted, "Most of the Merchants as well as others, ... preferred them [Virginia’s notes] either to Gold or Silver, as being more convenient for transacting the internal Business of the Country." William and Mary College Quarterly Historical Magazine (1912, p. 235). The public continued to use these notes to execute 
domestic transactions and let the full specie equivalent that backed them sit in the treasury.

\section{Value Decomposition}

\section{a. My Decomposition Model for Inside Monies}

I apply my decomposition approach to evaluate Virginia’s paper money performance (Celia and Grubb 2016; Grubb 2014, 2016). The observable market exchange value (MEV) of this money is decomposed into its component parts, see equation (2). ${ }^{4} \mathrm{MEV}$ equals its expected real-asset present value (APV - RD), i.e. its value as just another non-money barter asset, plus its transaction premium (TP) that measures its pure “moneyness” value, i.e. its extra value as a transacting medium of exchange. Positive values for TP measure the willingness of the public to pay a premium above the notes' expected real-asset present value, because the notes served as a more convenient transacting medium than the next best barter alternative. The expected realasset present value is further separated into it pure time-discounting component (APV), and its default risk component (RD). All components in equation (2) are calculated as a percentage of face value to be in a comparable metric.

$$
\mathrm{MEV}_{\mathrm{t}}=(\mathrm{APV}-\mathrm{RD})_{\mathrm{t}}+\mathrm{TP}_{\mathrm{t}}
$$

If $\mathrm{MEV} \approx \mathrm{APV}$, with $(\mathrm{TP}-\mathrm{RD}) \approx 0$, then Virginia's paper money is just a low-risk barter asset with no value as “money” beyond that of the next best barter alternative. If MEV $\approx(A P V$ $\mathrm{RD}$ ), with $\mathrm{TP} \approx 0$, then Virginia's paper money is just a risky barter asset. If $\mathrm{MEV} \approx \mathrm{TP}$, with $(\mathrm{APV}-\mathrm{RD}) \approx 0$, then Virginia's paper money is a pure fiat currency. Colonial paper monies likely operated somewhere between these extremes. The decomposition in equation (2) is used to

\footnotetext{
${ }^{4}$ This decomposition has some resemblance to the discussions of paper money by Benjamin Franklin in 1729 (Labaree 1959, v. 1, p. 153); by Gouverneur Morris in 1778 (Barlow 2012, pp. 73-76); and by James Madison in 1779 (Hutchinson and Rachal 1962, v. 1, pp. 305-06). As such, it can be considered consistent with how some prominent colonial Americans thought about their paper money. It also has some resemblance to the theory of money presented by John Maynard Keynes in the General Theory (1991, pp. 222-44 [chapter 17]) and could be considered an exercise to operationalize and apply that theory. This decomposition can also be thought of as a simple hedonic pricing exercise for the bundle of attributes that comprise a physical exchange instrument.
} 
disentangle the extent that Virginia's paper money functioned as a commodity or real-asset medium of exchange ((APV - RD) / MEV) versus as a fiat currency (TP / MEV).

Legislatures controlled APV and RD. They controlled APV by choosing the redemption structure, and they influenced RD by how they followed through on that redemption structure. TP was determined by the public through the structure of the economy in terms of how the public evaluated and used alternative media of exchange to execute domestic transactions.

Empirical measurement is the difficult part of applying this approach. Theory is easy; application is hard. While I can measure MEV using data on exchange rates to an outside money, $\mathrm{RD}$ and TP cannot be independently measured. In addition, measuring APV entails constructing a counterfactual value of the notes, namely their value when not used as money and when no risk of default is expected. Given that they are being used as money, constructing this counterfactual and disentangling it from MEV requires attention.

Fortunately, Virginia's treasury notes were structured as zero-coupon bonds, except for the 1755-6 emissions that were structured as interest-bearing bonds. ${ }^{5}$ The notes had legally defined end maturity dates when they were paid off at face value in specie equivalents by Virginia's government, and they could be redeemed at face value for tax payment obligations any time after initial emission. Given expected redemption time-paths and end maturity dates, payoff values, and an appropriate risk-free time-discount rate, the APV of these notes as risk-free non-money tradable bonds can be calculated independent of their MEV.

Moving the variables that can be independently measured to the left-hand side, and the variables that cannot be independently measured to the right-hand side, yields equation (3). In terms of proportions, the ratio $\mathrm{APV}_{\mathrm{t}} / \mathrm{MEV}_{\mathrm{t}}$ shows how much of $\mathrm{MEV}_{\mathrm{t}}$ is accounted for by $\mathrm{APV}_{\mathrm{t}}$

\footnotetext{
${ }^{5}$ Benjamin Franklin (Labaree 1967, v. 11, pp. 13-15), Adam Smith (1937, pp. 310-12), and James Madison (Hutchinson and Rachal 1962, v. 1, pp. 305-06) described colonial bills of credit as zero-coupon bonds.
} 
with the residual share being accounted for by (TP - RD)t. The gap between $M E V_{t}$ and $A P V_{t}$, measures the magnitude of (TP - RD). The possibility that $\mathrm{TP}_{t}$ and $\mathrm{RD}_{\mathrm{t}}$ are both greater than zero by large magnitudes at the same time is unlikely. An asset with a high default risk would be unlikely to possess a transaction premium, i.e. be the preferred medium of exchange, relative to an asset with a low default risk. ${ }^{6}$ Thus, when $(\mathrm{TP}-\mathrm{RD})_{\mathrm{t}}>0$, it is primarily due to $\mathrm{TP}_{\mathrm{t}}>0$; and when $(\mathrm{TP}-\mathrm{RD})_{\mathrm{t}}<0$, it is primarily due to $\mathrm{RD}_{\mathrm{t}}>0$.

$$
\left(M E V_{t}-A P V_{t}\right)=(T P-R D)_{t}
$$

\section{b. MEV and APV Data}

To apply equation (3), two data sets are required. I must compile the market exchange value (MEV) of Virginia’s notes between 1755 and 1774, and I must calculate the counterfactual expected real-asset present value (APV) of Virginia's notes as non-money low-risk bonds. I use the observed market exchange rates between Virginia’s notes and bills of exchange paying pounds sterling in London to construct MEV. These exchange rates are primarily from merchant account books and are expressed as the face value amount of Virginia notes needed to buy, in Virginia, a 100 pound sterling bill of exchange drawn on London (McCusker 1978, pp. 205-14). I adjusted these exchange rates to account for the cost of getting a bill of exchange to London and getting it liquidated into specie usable in Virginia. I estimated that cost to be 7.09 percent. $^{7}$ Thus, the realized par exchange rate of a Virginia note is $116.14 £_{\mathrm{VA}}=100 £_{\mathrm{S}}$ compared

\footnotetext{
${ }^{6}$ While it is mathematically possible for (TP - RD) to equal 1 percent of face value because $\mathrm{TP}=1$ percent and $\mathrm{RD}$ $=0$ percent, or because $\mathrm{TP}=100$ percent and $\mathrm{RD}=99$ percent, the later possibility is absurd in practice. Behaviorally, TP is likely a negative function of RD. Thus, as RD takes on positive values, TP is quickly driven to zero. People select a particular thing as money because it has certainty to its forecasted value. See also, Keynes (1991, pp. 222-44 [chapter 17]). The transaction premium (TP) is not about convenience per se. It is about how much people are willing to pay for this convenience above the convenience value of the next best alternative medium of exchange. TP is an opportunity cost measure.

${ }^{7}$ This information is derived from the exchange rates quoted before bills of credit were ever issued (McCusker 1978, p. 172). In addition, The Boston Evening Post, 25 October 1773, estimated the cost of shipping specie between the colonies and London to be 6 percent. It was comprised of 2.5 percent for insurance and brokerage, 2.5 percent for commissions, and 1 percent for freight (Brock 1992, pp. 74, 124). Adding the opportunity cost of time raises the
} 
with the legal par exchange rate of $125 £_{\mathrm{VA}}=100 £_{\mathrm{S}}$ (Hening 1969, v. 6, pp. 478-83). MEV is calculated by dividing this adjusted number (116.14) by the observed exchange rates in McCusker (1978, pp. 211-2). Compared with using the legal par exchange rate, using the realized par rate as the numerator makes MEV a smaller percentage of face value. MEV measures the spot-market conversion in Virginia of Virginia paper pounds into a silver commodity outside money expressed as a percentage of the face value of Virginia paper pounds. The MEV data are presented in Appendix Table A1. Given uncertainty over the exact transaction cost underlying the adjustment to the legal par rate, an MEV within in a percentage point of that report in Appendix Table A1 is certainly possible.

Virginia’s paper money had a bearer-bond quality that required an explicit redemption exercise to extinguish the principal expressed on the note's face. Virginia's citizens are assumed to act as if they understood their paper money to be interest-bearing bonds in 1755-6, and zerocoupon bonds thereafter, requiring time-discounting to ascertain their present value (their APV), and to know how to calculate this value. ${ }^{8}$ The public is also assumed to know the quantity of notes in circulation $\left(\mathrm{M}_{\mathrm{j}}\right)$ and the amounts redeemed $\left(\mathrm{RED}_{\mathrm{t}}\right)$ each year as shown in Table 2, with $\mathrm{RED}_{\mathrm{t}}$ including the amount of funds (specie) in the treasury that could be used for redemption at face value at the end maturity dates of the notes as shown in Tables 1 and 2.

At a given point in time, notes with different redemption dates would have different APVs. Seemingly identical notes with differing present values (APVs) at the same point in time makes for a cumbersome medium of exchange. Virginia’s legislature attempted to solve this problem with redemption rule changes in June 1757, November 1761 (subsequently suspended by the Board of Trade in 1763), and July 1774. These rule changes made all notes currently specie across the Atlantic from 1760 through 1765, was approximately 7.46 percent (Bush 1982, pp. 10-13, 315-16).

${ }^{8}$ E.g. see Labaree (1967, v. 11, pp. 13-15); Ricord (1892, v. 17, p. 159); Smith (1937, pp. 310-12). 
outstanding on those dates have a new common redemption date and so a common APV.

For the most part, the evidence does not record what notes from which emissions were redeemed when. Occasionally the notes from particular emissions are identified as being burnt on a specific date, but more often redemption evidence lumps notes from all emissions currently outstanding together (Grubb 2015). Given legal tender laws, notes from any emission currently outstanding could be used to pay any current taxes. For these reasons, I assume that the public responded only to the expected redemption of the average note currently outstanding. Because the MEV data from McCusker (1978) measures the current market value of the average note in circulation, and does not distinguish between the notes of different emissions, APV is calculated to measure the pure time-discounted present value of the average or representative note currently outstanding. Thus, MEV and APV are comparable measures.

Equation (4) shows how the expected APV of the average note in circulation is calculated. The amount of Virginia paper money outstanding in a given year is assumed to be redeemed by all notes actually redeemed in the immediately following years, including the potential redemption at the end maturity date using accumulated specie in the treasury, until the year when that original amount is fully redeemed. These yearly redemption amounts are divided by the initial amount outstanding from the chosen year to assign a yearly weight to its contribution in the redemption process. The time discounts between the initial year and the redemption year are multiplied by the contribution-weights for their respective years. The timediscount-weight values for each year are summed to get the expected present value of a representative note outstanding for that chosen year. The APV calculation is adjusted for 1755-6 to account for the interest actually paid (Grubb 2015). 


$$
\mathrm{APV}_{\mathrm{j}}=\sum_{t=\mathrm{j}}^{\mathrm{N}}\left(\mathrm{RED}_{t} / \mathrm{M}_{\mathrm{j}}\right) e^{-r t}
$$

Where $r$ = the risk-free time-discount rate or opportunity cost of capital, $\mathrm{M}_{\mathrm{j}}=$ the face value amount of Virginia paper money outstanding in year $\mathrm{j}, \mathrm{RED}_{t}=$ the face value amount of Virginia notes redeemed and retired from circulation each year, including the amount of funds (specie) in the treasury that could be used for redemption at face value at the end maturity dates of the notes, with $\mathrm{RED}_{\mathrm{N}}$ being the amount in the last year $\mathrm{N}$ that satisfies:

$$
\sum_{t=\mathrm{j}}^{\mathrm{N}}\left(\mathrm{RED}_{t} / \mathrm{M}_{\mathrm{j}}\right)=1 \text {. }
$$

No time-series of market-generated interest (discount) rates for any class of assets currently exists for colonial America. Therefore, I use the $r$ considered normal by colonial contemporaries for assets with relatively low default expectations. This rate is used as a proxy for what in modern analysis is designated as the risk-free rate. In 1748, the Virginia assembly set the legal interest rate for the colony at 5 percent, where it stayed for the rest of the colonial period. However, the legislature indicated that the market rate was above this legal rate (Hening 1969, v. 6, pp. 101-04). In 1764, Benjamin Franklin stated that the rate for discounting wellfunded legislature-issued zero-coupon bonds was 5 or 6 percent (Labaree 1967, v. 11, pp. 13-15). The interest rate mentioned most often for the middle colonies in the second half of the eighteenth century was 6 percent. ${ }^{9}$ Earlier in the century, and perhaps during wars, the rate may have been slightly higher. Given uncertainty over the exact rate, an $r$ from 5 through 7 percent is used, with 6 percent being my best guess. The APV using discounts rates of 5, 6, and 7 percent

\footnotetext{
${ }^{9}$ See Barlow (2012, pp. 110, 125, 128); Brock (1975, pp. 260, 328, 332, 435, 462); Catanzariti, et al, (1988, v. 7, p. 547); Davis (1964, v. 1, p. 326; v. 2, pp. 38, 68, 83, 99-100, 315, 321; v. 3, p. 168; v. 4); Documents Relating to the Colonial History of the State of New Jersey (v. 5, p. 91); Elliot (1843); Homer and Sylla (1991, pp. 274-313); Hutchinson and Rachel (1962, v. 1, p. 308); Journals of the Continental Congress (v. 2, pp. 25-26; v. 6, p. 1037; v. 7, pp. 102-03, 158, 168; v. 8, pp. 725-26; v. 9, pp. 955, 989; v. 10, p. 59; v. 11, p. 416; v. 12, pp. 929-30, 932, 1074, 1256; v. 13, pp. 112, 141, 146-47, 441, 497; v. 14, pp. 717, 720, 731-32, 783, 820, 901; v. 15, pp. 1147, 1197, 1210, 1225, 1245-46, 1288, 1319, 1405; v. 16, pp. 264-65, 288; v. 17, pp. 464, 568, 804; v. 18, p. 1017; v. 19, pp. 6, 167; v. 21, p. 903; v. 23, p. 831; v. 24, p. 39; v. 26, p. 32; v. 27, pp. 395-96); Labaree (1959, v. 1, p. 142; 1967, v. 11, pp. 13-15); Nettels (1934, p. 267); Pennsylvania Gazette (30 April; 21 and 28 May; 25 June; 2, 16, and 23 July 1777); Smith (1979, v. 4, p. 295; 1980, v. 6, pp. 117-18, 212-13, 228-29, 238-39, 245, 252, 259-62, 270, 277, 295, 346, 368, 372, 386, 400-01, 404; 1981, v. 7, pp. 524, 581, 617, 623, 635, 642-43; 1981, v. 8, p. 25; 1983, v. 10, p. 205; 1985, v. 11, pp. 94, 137-38, 361; 1986, v. 13, pp. 132, 604-05; 1987, v. 14, pp. 51, 463, 500; 1988, v. 15, pp. 377, 396; 1989, v. 16, pp. 307-08, 490, 531; 1990, v. 17, p. 365; 1992, v. 19, p. 139; 1994, v. 21, p. 467).
} 
are reported in Appendix Table A1.

$\mathrm{APV}_{\mathrm{j}}$ is not mechanically linked to $\mathrm{M}_{\mathrm{j}}$. For any given $\mathrm{M}_{\mathrm{j}}, \mathrm{APV}_{\mathrm{j}}$ can take on any value between 0 and 100 percent of face value, because the legislature has unrestricted choice over $\mathrm{N}$ and $\mathrm{RED}_{\mathrm{t}}$. Given $r, \mathrm{APV}_{\mathrm{j}}$ is under the control of the legislature through its legal design and execution of its paper money laws.

\section{c. An Alternative Method: Imputing $r^{*}$}

I employ an alternative method to get at the same issue. If $\mathrm{TP}=0$, then $\mathrm{MEV}$ measures the current spot market value of these notes as non-money bonds. Given the expected redemption structure, the interest rate $r^{*}$ that makes $\mathrm{MEV}=(\mathrm{APV}-\mathrm{RD})$ is calculated, i.e. select $r^{*}$ such that

$\mathrm{MEV}_{\mathrm{j}}=\sum_{t=\mathrm{j}}{ }^{\mathrm{T}}\left(\mathrm{RED}_{t} / \mathrm{M}_{\mathrm{j}}\right) e^{-r^{*} t}$. If in fact TP $=0$, then $r^{*}$ represents the first time-series of marketgenerated interest rates for any class of assets in colonial America, see Appendix Table A1.

If $r^{*}$ is within the normal range of risk-free discount rates, then the proposition that the notes are simply non-money barter assets with no special “moneyness” value or fiat currency attributes cannot be rejected. If $r^{*}$ is above this range, then nothing changes from the above conclusion except that now $\mathrm{RD}>0$, namely the notes are risky non-money bonds. If $r^{*}$ is below this range, then the proposition that $\mathrm{RD} \approx 0$ and $\mathrm{TP}>0$, namely that the bills have some “moneyness” value, cannot be rejected. The magnitude by which $r^{*}$ is outside the normal range of interest rates measures the extent that $\mathrm{RD}>0$ when $r *$ is above that range, and the extent that TP $>0$ when $r^{*}$ is below that range.

\section{The Compositional Analysis of MEV: MEV, APV, and $\mathbf{r}^{*}$ through Time}

Figure 1 compares the levels of MEV and APV over time, when APV is discounted at 5, 6, and 7 percent. MEV could be within a percentage point of that drawn due to measurement error in the transacting cost of liquidating sterling bills of exchange drawn on London and 


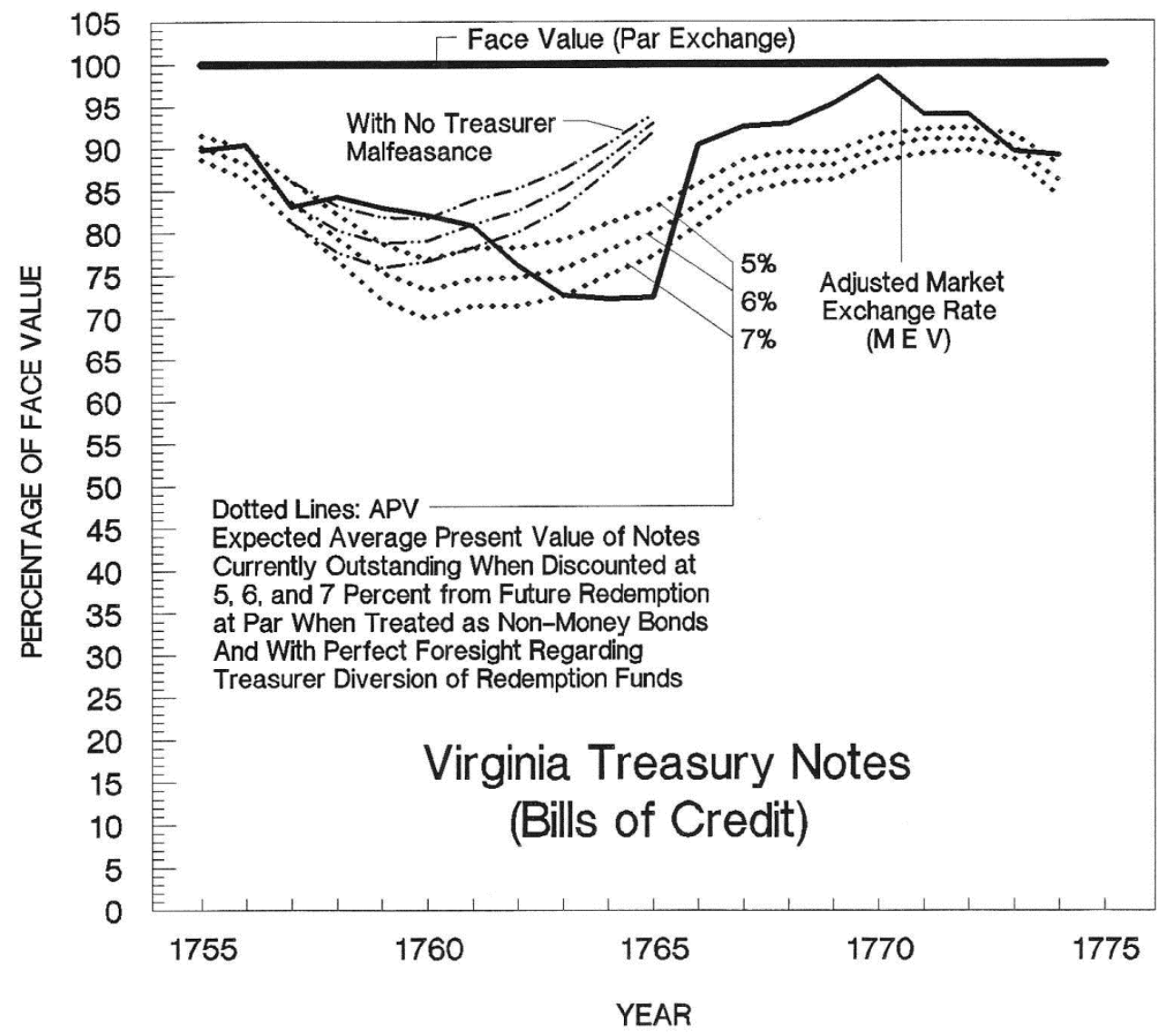

Figure 1 MEV versus APV, 1755-1774

Sources: Appendix Table A1.

turning them into specie usable in Virginia. While 6 percent is my best-guess discount rate, uncertainty over that rate means that 5 or 7 percent could also be used. Considering the range of possible measurement error in MEV and uncertainty over which discount rate to use for APV, the hypothesis that MEV is primarily and predominantly comprised of APV cannot be rejected given the data in Figure 1. Little (TP - RD) figures in to MEV. Virginia treasury notes were not a fiat currency. They were predominantly real barter assets.

Using MEV as drawn and the best-guess 6 percent discount rate, over the entire period covered by colonial Virginia’s paper money regime APV accounts for 97 percent of MEV, leaving TP to account for only 3 percent of MEV. Within this overall span, four sub-periods can 
be identified. MEV $\approx$ APV from 1755 through 1757, implying that $(T P-R D)=0$ during the initial three years of Virginia's paper money regime. Being a new endeavor for Virginia, the notes possessing no TP in these initial years is not surprising.

By comparison, $\mathrm{MEV}>\mathrm{APV}$, implying that $\mathrm{RD} \approx 0$ and $\mathrm{TP}>0$, in the years 1758-62 and 1766-74. The years 1758-62 and 1766-72 appear to be normal in that no specific financial crises are identifiable. In these normal years, APV accounts for 93-94 percent of MEV leaving TP to account for 6-7 percent of MEV. While relatively small, this TP was enough to make Virginia's treasury notes the preferred media of exchange for executing domestic transactions. The public was willing to pay somewhere between 6 and 7 percent over the notes' expected average realasset present value to possess the notes because the notes had a "moneyness" value over and above the next best barter alternative. This 6 to 7 percent can be considered a measure of the transaction cost gains from using notes, compared with using book credit, tobacco claims, or specie, to execute domestic transactions.

\section{a. The John Robinson Scandal at the Treasury}

In the sub-period $1763-5, \mathrm{MEV}<\mathrm{APV}$, implying that $\mathrm{TP} \approx 0$ and $\mathrm{RD}>0$. This period is associated with a financial crisis that preoccupied Virginia politics. ${ }^{10}$ John Robinson, treasurer and speaker of the house from 1738 until his death in early 1766, had been suspected of diverting funds accumulating in the treasury, funds earmarked for redeeming notes at their end maturity dates. He loaned these funds, without specific authority to do so, to his friends. In 1766, after his death, it was discovered that just over 95,000 $£_{\mathrm{VA}}$ of these funds had been so diverted. ${ }^{11}$ Given the large amount diverted, the suspicions expressed at the time that such was happening seem

\footnotetext{
${ }^{10}$ Brock (1975, pp. 465-527) does not mention the John Robinson scandal. He speculates that the exchange rate crisis of the early 1760s was due to gyrations in tobacco production and troubles in the bills-of-exchange market. ${ }^{11}$ Scholars have typically claimed that these diverted funds were notes put back in circulation. This claim turns out to be presumption predicated on erroneous logic. There is no evidence that these diverted funds were notes. The forensic accounting exercise indicates that these diverted funds were predominantly specie, see Grubb (2015).
} 
credible (Ernst 1973, pp. 177, 183, 188; Lee 1825, pp. 22-3; Mays 1952, pp. 175, 181). The evidence in Figure 1 is consistent with the public becoming suspicious of improprieties around 1761, judging by the shrinking TP that starts after 1760. (TP - RD) does not become negative until 1763, which is consistent with the public definitely responding to something being amiss at the treasury regarding potential note redemption.

Given that a substantial amount of notes in circulation in the early 1760 s had their end maturity dates between 1765 and 1769, see Table 1, the public had to be concerned in the early 1760s that the accumulating tax funds in the treasury earmarked to redeem these notes would not be there when so required for redemption. A letter in the Virginia Gazette, 17 October 1766, remarked that "Many of us, to our great detriment, have had money paid to us whose day of redemption was elapsed, and which some of our creditors refused to receive from us again, alleging it was no currency; this money, when carried to the Treasury has frequently been refused to be redeemed, under the pretense that the Treasury was empty,...” Fear of delayed redemption led the public to eliminate any TP and then to add a positive RD to the notes by 1763. The data in Figure 1, using the best-guess 6 percent discount rate, indicates that the RD in 1763-6, assuming TP $\approx 0$, accounted for an average of 7.5 percent of MEV. In other words, MEV = APV - RD in these years. The notes in this period functioned like risky barter assets.

Figure 1 illustrates what the APV would have been if there was no diversion of treasury funds, with those funds remaining in the treasury to execute note redemption as legislated. Between 1763 and 1765, using the best-guess 6 percent discount rate, APV would have been 11 percentage points higher with no treasurer diversion of redemption funds. I construct a counterfactual MEV for the years 1763-5 using this alternative higher APV by assuming MEV= APV + TP, where the TP is taken from the prior normal years of 1758-62, and RD is assumed to 
be zero. In the absence of treasurer malfeasance, MEV would have averaged 96 percent of face value in $1763-5$ as opposed to its actual 72 percent of face value-a 24 percentage point effect on MEV. The exchange rate crisis of the early 1760s can be fully accounted for by the treasurer's diversion of redemption funds (Ernst 1973, p. 194).

After Robinson died in early 1766 and his actions were fully documented, MEV and APV rapidly returned to normal patterns. Robinson's estate was required to repay the sums diverted. The slow repayment of these funds, and the resumption of normal tax payments and use of the specie portion to redeem notes, meant the return to normal expected redemption processes. b. The 1773 Counterfeiting Scare

Early in 1773, notes of the 1769 and 1771 emissions were discovered to have been counterfeited “...in so ingenious and dangerous a manner that it is difficult to distinguish the forged from the good bills,...” (Hening 1969, v. 8, p. 648; Kennedy 1905, pp. viii-xi, 7, 9-10, 267) The assembly moved swiftly to mitigate the impact. They required all notes from emissions \#14 and \#15 still outstanding to be swapped for new notes in 1773 and hunted down the counterfeiters (Hening 1969, v. 8, pp. 647-51; Kennedy 1905, pp. viii-xi, 7, 9-10, 15-16, 18-20, 23-4, 27, 29-32, 35, 264). If the public expected the actions of the assembly to be ineffectual, they would have discounted the notes severely, i.e. generated a $\mathrm{RD}>0$ into the near future, to account for the risk that not all notes could now be redeemed as legislatively promised and that their notes might be rejected in trade or for redemption at the treasury because they might be counterfeit (Ernst 1973, pp. 331-4).

Figure 1, however, shows that this counterfeiting scare, while a topic of public discussion and legislative action, had little impact on the value of the notes in circulation. Using the bestguess 6 percent discount rate, MEV exceeds APV in 1772 and 1774 by the normal TP amounts. 
In $1773, \mathrm{MEV} \approx \mathrm{APV}$, thus leaving $(\mathrm{TP}-\mathrm{RD}) \approx 0$. No significant $\mathrm{RD}>0$ appears in this period. At best, a 4 to 6 percentage point dip and then return in TP occurs from 1772 to 1773 to 1774 .

This result is important because stories of counterfeiting have given the impression that colonial bills of credit were problematic monies or even worthless monies (Ernst 1973, pp. 3314; Scott 1957). The evidence in Figure 1 indicates that counterfeiting had a minor and very temporary economic impact on the value and performance of Virginia's paper money. While this is the first systematic quantitative measure of the impact of a significant counterfeiting episode on the value of colonial paper monies, it raises the possibility that counterfeiting is an overdramatized topic. Colonial governments had the tools to mitigate the impact of counterfeiting quickly and almost completely, and they employed these tools when necessary.

c. The $r^{*}$ Analysis

Figure 2 shows the same results from an alternative angle. It displays $r *$ from 1755 through 1774 along with the legal interest rate and my best-guess normal time-discount rate of 6 percent. In the first three years of the paper money regime, 1755-7, $r *$ is around the normal range of risk-free discount rates, implying that the notes’ MEV is largely determined by APV. The notes are primarily a low risk barter asset in these years.

The imputed $r^{*}$ drops well below the risk-free discount rate from 1758 through 1762, and again from 1766 through 1772 . These below-normal $r *$ rates do not represent the normal market rate being driven down by an increased emission of paper money. No contemporary writer or any other evidence indicates that normal interest rates were as low as $r^{*}$ in these years, and in the second period the amount of notes in circulation experienced substantial contraction not expansion. In other words, the proposition, $\mathrm{TP}>0$, cannot be rejected in these years.

Figure 2 also shows the periods when RD $>0$ due to suspicion of potential non- 


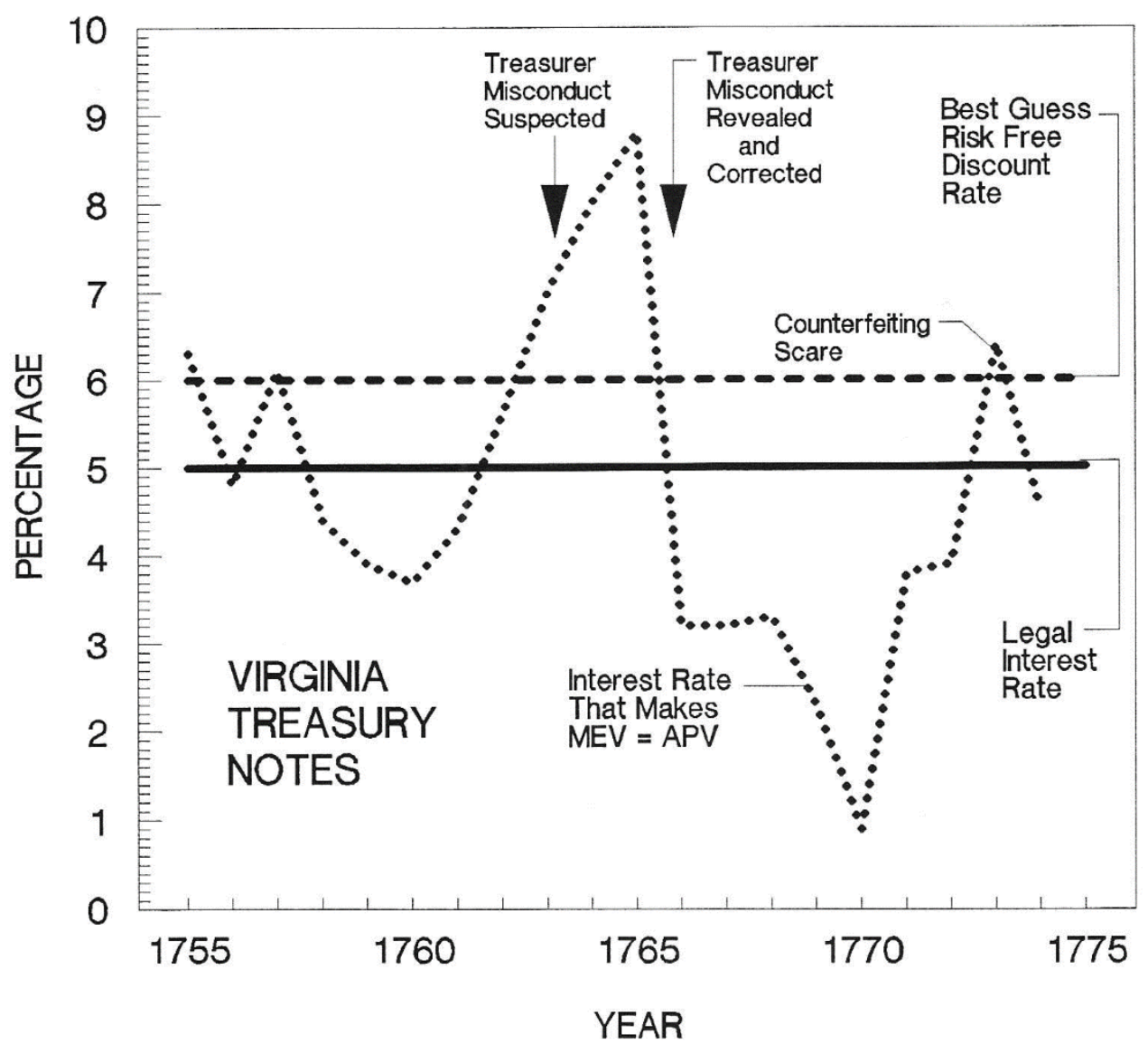

Figure $2 \quad r *$ through Time, 1755-1774

Sources: Appendix Table A1.

redemption. The malfeasance suspected and then revealed at the treasury between 1763 and 1766 appears as a spike in $r^{*}$, reaching 9 percent by 1765 before returning to its typical non-crisis range thereafter. Because no evidence indicates that risk-free discount rates were ever in the 9 percent range, this finding implies that $\mathrm{TP} \approx 0$ and $\mathrm{RD}>0$ in these years. The notes were risky barter assets in these years. Figure 2 also shows the relatively minor nature of the counterfeiting scare in 1773 . While the scare briefly eliminated any $\mathrm{TP}>0$ attached to the notes, it left there use in the range of free-risk barter assets, rather than risky barter assets.

\section{Statistical Properties}

Table 3 reports the time series statistical properties of MEV and APV, using the 


\begin{tabular}{|c|c|c|c|c|c|c|c|}
\hline \multirow{2}{*}{\multicolumn{3}{|c|}{ Panel A. MEV stationarity test: $\left(\mathrm{MEV}_{\mathrm{t}}-\mathrm{MEV}_{\mathrm{t}-1}\right)=$}} & \multicolumn{4}{|c|}{ Adjusted } & \multirow{2}{*}{$\begin{array}{l}\text { Half-life } \\
\text { in years }\end{array}$} \\
\hline & & & Lags & $N$ & $R^{2}$ & $F$ & \\
\hline $\begin{array}{ll}1339.1400^{* * *}- & 0.5955\left(\mathrm{MEV}_{\mathrm{t}-1}\right)^{* * *} \\
(433.5551) & (0.1110)\end{array}$ & $\begin{aligned}- & 0.7341(\mathrm{YEAR})^{* * *} \\
& (0.2450)\end{aligned}$ & $\begin{array}{l}+17.0178(\mathrm{D})^{* * *} \\
\quad(3.1831)\end{array}$ & 0 & 19 & 0.67 & $13.75^{* * *}$ & 0.77 \\
\hline
\end{tabular}

Panel B. APV6 stationarity test: $\left(\mathrm{APV6}_{\mathrm{t}}-\mathrm{APV6}_{\mathrm{t}-1}\right)=$

\begin{tabular}{|c|c|c|c|c|c|c|}
\hline $\begin{array}{l}23.7956^{* * *} \\
(5.8349)\end{array}$ & $\begin{aligned}- & 0.3049\left(\text { APV6 }_{\mathrm{t}-1}\right)^{* * *} \\
& (0.0756)\end{aligned}$ & $\begin{array}{l}+2.6552(\mathrm{D})^{* *} \\
(1.1219)\end{array}$ & 1 & 18 & 0.79 & $22.32^{* * *}$ \\
\hline
\end{tabular}

Panel C. $\mathrm{MEV}_{\mathrm{t}}$ versus APV6 $\mathrm{t}: \mathrm{MEV}_{\mathrm{t}}=$

\begin{tabular}{|c|c|c|c|c|c|c|}
\hline $\begin{aligned}+ & 0.6580\left(\mathrm{APV6}_{\mathrm{t}}\right)^{* *} \\
& (0.2426)\end{aligned}$ & & 1 & 19 & 0.73 & $25.40^{* * *}$ & \\
\hline Co-integration test: $\left[z_{t}-z_{t-1}\right]=$ & $\begin{array}{l}0.0324-0.8342\left(z_{\mathrm{t}-1}\right)^{* *} \\
(0.9957) \quad(0.2464)\end{array}$ & 0 & 18 & 0.38 & $11.46^{* * *}$ & 0.38 \\
\hline
\end{tabular}

Panel D. Transaction premium determinants: $\left(\mathrm{MEV}_{\mathrm{t}}-\mathrm{APV}_{\mathrm{t}}\right)=\left(\mathrm{TP}_{\mathrm{t}}-\mathrm{RD}_{\mathrm{t}}\right)=$

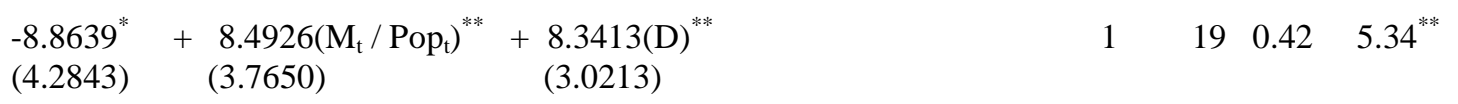

Sources: Figure 1; Appendix Table A1. See text and Appendix Table A1 for variable definitions.

Notes: Data are annual. Standard errors are in parentheses under their respective coefficients. Lags refers to lagged dependent variables included to removal serial correlation (coefficients not reported). D is a structural break dummy variable capturing the change in treasurers and so the end of the diversion of redemption funds, see the text. $\mathrm{D}=1$ for years 1766-1774 and zero otherwise. The D selected yields a local maximum regression fit. If the initial year for $\mathrm{D}$ is moved one year forward or one year backward from that reported here, the regression fit is reduced. $z_{\mathrm{t}}=$ regression error term. Dickey-Fuller critical values are used for the (t-1) independent variables in panels A, B, and C, see Enders (1995, p. 419). For panel A, Durbin’s Alternative Tests for autocorrelation failed to reject the hypothesis of no serial correlation above the 0.1 level. For the regression in panels $\mathrm{B}$, $\mathrm{C}$, and $\mathrm{D}$, serial correlation was corrected by including one lag of the dependent variable (coefficients not reported). This corrected regression was tested with Durbin's Alternative Test for autocorrelation which failed to reject the hypothesis of no serial correlation above the 0.1 level. The half-life to shocks are calculated using the following equation: [- $\ln (2) / \ln (1+$ $\left.a_{* * *}\right)$, where $a_{1}$ is the coefficient on the (t-1) independent variable in panels A, B, and C. See Mark (2001, p. 32).

${ }^{* * *}$ Statistically significance above the 0.01 level.

** Statistically significance above the 0.05 level.

* Statistically significance above the 0.1 level.

best-guess 6 percent discount rate for APV. MEV is a trend stationary series, with a structural

break at 1766 . APV is a stationary series with a structural break at 1766 . Both have short half-

lives to shocks. MEV and APV are also co-integrated. Thus, estimating APV's effect on MEV

over time is a valid exercise. Panel $\mathrm{C}$ in Table 3 reports that effect. APV $\mathrm{V}_{\mathrm{t}}$ has a statistically

significant positive effect on $\mathrm{MEV}_{\mathrm{t}}$ with a relatively large coefficient magnitude. Statistically, 
APV and MEV are closely associated. MEV tracks APV through time.

I estimate the determinants of TP, i.e. the determinants of the "moneyness" value of Virginia's treasury notes, net of RD, in Table 3, panel D. (TP - RD)t is measured by (MEV APV), see equation (3). Because (TP - RD) cannot be decomposed empirically, careful interpretation of the independent variables is required to assess $\Delta \mathrm{TP}$ versus $\Delta \mathrm{RD}$. Because $\mathrm{TP}$ is likely a negative function of $\mathrm{RD}$, behaviorally, with TP quickly driven to zero when $\mathrm{RD}$ takes on positive values, positive independent variables are likely capturing positive movements in TP. ${ }^{12}$

The regression explains 42 percent of the variance in (TP - RD)t. Controlling for the amount of notes in circulation per capita, the $1766-1774$ structural break variable is significantly associated with higher TP in those years, see also Figure 1. The structural break captures the shift from the old treasurer, John Robinson, who was suspected of malfeasance, to a new treasurer, Robert Carter Nicholas. This transition removed the RD that arose in the early 1760 s caused by suspicions that the specie in the treasury that was to be used to redeem notes had been misappropriated by Robinson, and allowed TP to once again take on positive values.

This result is also important for assessing the impact of the 1764 Currency Act that removed legal tender status from new issues of colonial paper money. The Parliamentary removal of legal tender status of colonial paper monies did not reduce the TP or "moneyness" value Virginians placed on their own treasury notes. Legal tender status apparently was not necessary for the notes to be the preferred medium of exchange in local transactions. Moving the structural break variable one year back or one year forward from 1766 reduces the regression fit, i.e. 1766 is a local maximum. This finding indicates that the 1764 Currency Act was a non-issue regarding the performance and value of Virginia's notes (Grubb 2016). The 1764 Currency Act was more a political issue, than an economic issue (Brock 1975, pp. 465-527; Ernst 1973).

\footnotetext{
${ }^{12}$ See fns. 4 and 6.
} 
The most interesting result in Table 3, panel $\mathrm{D}$, is the positive and significant effect of the amount of paper money per capita on (TP - RD). Placing more paper money in circulation regardless of which treasurer was in charge, increased the strain on executing redemptions as promised. As such, RD should not fall, and so increases in TP must account for this positive association. More paper money in circulation per capita increased its ubiquity and familiarity of usage, which in turn led the public to increasingly treat this money as fiat-like currency, namely adding value to the money above its real-asset present value. This process was accomplished by the public not time-discounting these notes when used in trade as much as would be required if they were just non-money zero-coupon barter bonds. As more paper money was put into circulation, it increasingly became the preferred medium of exchange for local transactions, as revealed by the fact that citizens were willing to pay a positive TP for it. As such, treasury notes increasingly displaced other means of making transactions, such as barter, book credit, tobacco claims, and specie coins.

This last result is an important finding for deciphering the performance of colonial paper monies. Because the transaction premium was positively associated with the quantity of paper money in circulation, it absorbed the pressure to reduce the value of the paper money that sprang from increases in the quantity of paper money. Within the limits of an under-monetized economy, increases in the quantity of paper money increased its "moneyness" value by increasing its usefulness as an internal medium of exchange within that economy. This association siphoned off or dampened the price inflation expected from increases in the paper money supply. As such, the classical quantity theory of money may perform poorly when used to assess the value and performance of colonial paper monies, compared with the application of my decomposition model of inside monies. 


\section{The Quantity Theory of Money}

The quantity theory of money has not been statistically applied to Virginia’s paper money regime before (Brock 1975, p. 476). Table 4, panel A, provides this application using a constructed price index $(\mathrm{P})$ as the dependent variable. The specification is adapted from West (1978, p. 4) so the results have some comparability with quantity-theoretic estimates done for other colonies. ${ }^{13}$ No statistically systematic relationships between prices and the quantities of paper money exist for Virginia. The results are the same as those found by West (1978) for South Carolina, Pennsylvania, and New York.

Panel B in Table 4 substitutes MEV in place of P. Prices are based on a small, though relatively important, number of goods. Prices also might not represent exchanges using paper money, as opposed to just being expressed in the paper money's unit-of-account. As such, the market exchange rate (MEV) between paper money and pounds sterling might be a better measure of value than prices in the quantity-theory-of-money formulation.

Under a quantity-theoretic approach, an increase in the amount of paper money, other things equal, should lead to an increase in prices, including an increase in the paper money price of sterling bills of exchange. An increase in the average sterling bill-of-exchange exchange rate, given that it is used as the denominator to calculate MEV, would cause MEV to fall. Thus, changes in MEV should be negatively associated with changes in M. Table 4, panel B, tests for this association. Replacing P with MEV does not improve the results. No statistically systematic relationships between MEV and the quantities of paper money exist for Virginia. The relative

\footnotetext{
${ }^{13}$ The classical quantity theory of money, at least a prominent version, takes the equation-of-exchange identity, MV $=\mathrm{PY}$, as expressed in growth rates, $\ln (\mathrm{M})+\ln (\mathrm{V})=\ln (\mathrm{P})+\ln (\mathrm{Y})$, and by assuming that $\ln (\mathrm{V})$ and $\ln (\mathrm{Y})$ are longrun constants transforms it into the quantity "theory" of money $[\ln (\mathrm{M})+$ some constant $=\ln (\mathrm{P})+$ some constant] or $[\ln (\mathrm{P})=$ some constant $+\ln (\mathrm{M})]$; where $\mathrm{M}=$ the money supply, $\mathrm{V}=$ the velocity of that money's circulation, $\mathrm{P}=$ prices in that money, and $\mathrm{Y}=$ traded real output (Bordo 1987; Fisher 1912). West (1978) set M equal to the paper money supply and estimated $\ln (\mathrm{P})=$ some constant $+\ln (\mathrm{M})$, including one and two-year lags of $\mathrm{M}$ to capture delayed effects of M on P. He estimated the model separately for South Carolina, Pennsylvania, New York, and Massachusetts. He found no relationship between prices and the quantity of paper money in the first three colonies.
} 


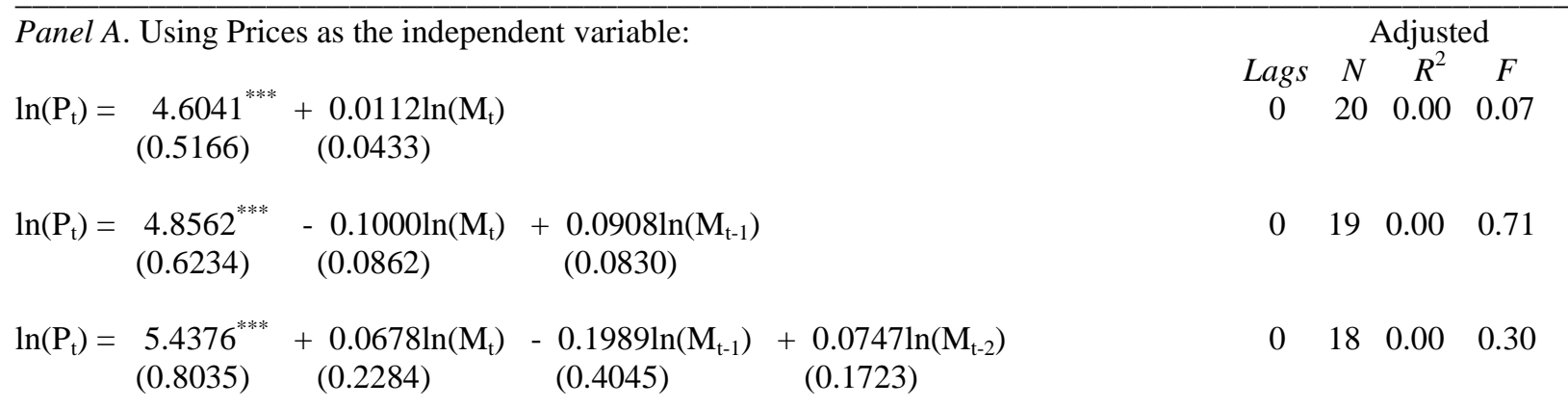

Panel B. Using MEV as the independent variable:

\begin{tabular}{|c|c|c|c|c|c|c|}
\hline $\ln \left(\mathrm{MEV}_{\mathrm{t}}\right)=\begin{array}{c}1.7925^{+} \\
(1.1053)\end{array}$ & $\begin{array}{c}-0.0345 \ln \left(\mathrm{M}_{\mathrm{t}}\right) \\
(0.0343)\end{array}$ & & 1 & 19 & 0.62 & $15.76^{* * *}$ \\
\hline $\ln \left(\mathrm{MEV}_{\mathrm{t}}\right)=\underset{(1.1887)}{1.7193^{+}}$ & $\begin{array}{c}-0.0422 \ln \left(\mathrm{M}_{\mathrm{t}}\right) \\
(0.0500)\end{array}$ & $\begin{array}{l}+0.01046 \ln \left(\mathrm{M}_{\mathrm{t}-1}\right) \\
\quad(0.0477)\end{array}$ & 1 & 19 & 0.60 & $9.90^{* * *}$ \\
\hline $\ln \left(\mathrm{MEV}_{\mathrm{t}}\right)=\underset{(1.4843)}{1.4136}$ & $\begin{array}{c}-0.0252 \ln \left(\mathrm{M}_{\mathrm{t}}\right) \\
(0.1338)\end{array}$ & $\begin{array}{cc}-0.0241 \ln \left(\mathrm{M}_{\mathrm{t}-1}\right)+ & 0.0305 \ln \left(\mathrm{M}_{\mathrm{t}-2}\right) \\
(0.2405) & (0.1009)\end{array}$ & 1 & 18 & 0.56 & $6.46^{* * *}$ \\
\hline
\end{tabular}

Sources: Appendix Table A1; Carter, et al (2006, v. 5, pp. 682-7).

Notes: Data are annual. Standard errors are in parentheses under their respective coefficients. For all panel A regressions, Durbin's Alternative Test for autocorrelation failed to reject the hypothesis of no serial correlation above the 0.1 level. For all panel B regressions, Durbin's Alternative Test for autocorrelation rejected the hypothesis of no serial correlation above the 0.1 level. With one lag of the dependent variable added (coefficients no reported), however, Durbin's Alternative Test for autocorrelation failed to reject the hypothesis of no serial correlation above the 0.1 level in all panel B regressions. $\mathrm{P}$ is an unweighted price index composed of York and Rappahannock River Basins tobacco prices, York River corn prices, and James River wheat prices, with $1755=100$. The raw average price for 1755 is 0.83 . Using only tobacco prices yields even weaker results.

${ }^{* * *}$ Statistically significance above the 0.01 level.

${ }^{* *}$ Statistically significance above the 0.05 level.

${ }^{*}$ Statistically significance above the 0.1 level.

${ }^{+}$Statistically significance above the 0.2 level.

high adjusted $\mathrm{R}^{2}$ is all due to serial correlation. No matter how you slice it, the quantity theory of money cannot explain the value and performance of Virginia’s paper money.

\section{Conclusion}

Colonial paper money is a Gordian knot. I have untied that knot. My decomposition

model of inside money explains the level and movement in the value of colonial Virginia’s paper money better than what has been done previously, either by alternative model estimations or by anecdotal story-telling. These are not marginal improvements, but quantum leaps in both 
conceptualization and modeling statistical performance.

Virginia’s paper money was predominantly a real barter asset with its real-asset present value explaining most of the level and movement in its observed market value. It functioned predominantly as a zero-coupon bond and not a fiat currency. It did, however, have a small transaction premium in normal years, enough to make it the preferred medium of exchange for domestic transactions. This transaction premium was positively related to the per capita quantity of paper money in circulation. As the quantity of paper money increased, it gained ubiquity and familiarity of use, leading citizens to pay a premium above its real-asset present value as it was now a better medium of exchange for executing local transactions than the next best alternative. In effect, citizens reduced the time-discounting they applied to the notes, thereby beginning a transition of the notes from being a barter asset toward having fiat currency characteristics. This process identifies one mechanism by which asset monies can transition into a fiat currency. This positive association of a transaction premium with the quantity of paper money in circulation, within an under-monetized economy, also siphoned off price inflation pressures coming from increases in the paper money supply. Finally, in years with monetary troubles, i.e. redemption worries, the paper money experienced a moderate risk discount to its real-asset present value. Counterfeiting, however, was not a major worry. The legislature had the tools and used them to effectively mitigate and stop the effect of counterfeiting on the value of its paper money. The value and performance of Virginia's paper money are consistently and coherently explained over its entire history, both conceptually and statistically, by my decomposition model for inside monies. 


\section{References}

Barlow, J. J. (ed.) 2012. To Secure the Blessings of Liberty: Selected Writings of Gouverneur Morris. Indianapolis, IN: Liberty Fund.

Breen, T. H. 1985. Tobacco Culture: The Mentality of the Great Tidewater Planters on the Eve of the Revolution. Princeton, NJ: Princeton University Press.

Bordo, M. D. 1987. Equation of exchange. In The New Palgrave: A Dictionary of Economics. Vol. 2, edited by J. Eatwell, M. Milgate, and P. Newman, 175-7. London: Macmillan.

Brock, L. V. 1975. The Currency of the American Colonies, 1700-1764. New York: Arno.

Brock, L. V. 1992. The colonial currency, prices, and exchange rates. Essays in History 34, 70-132 [posthumously published].

Bush, B. (ed.) 1982. Laws of the Royal Colony of New Jersey, 1760-1769. Trenton, NJ: New Jersey State Library, Archives and History Bureau.

Carter, S. B., et al. (eds.) 2006. Historical Statistics of the United States Earliest Times to the Present Millennial Edition, Volume 5. New York: Cambridge University Press.

Catanzariti, J., Nuxoll, E. M., Gallagher, M. A., et al., eds. 1988. The Papers of Robert Morris, 1781-1784, Vol. 7. Pittsburgh, PA: University of Pittsburgh Press.

Celia, J. and Grubb, F. 2016. Non-legal-tender paper money: the structure and performance of Maryland's bills of credit, 1767-1775. Economic History Review, forthcoming.

Davis, A. M. 1964. Colonial Currency Reprints, 1682-1751, Vols. 3-4. New York: Augustus M. Kelly.

Documents Relating to the Colonial History of the State of New Jersey 3-27, (1881-1905).

Elliot, J. 1843. Funding system of the United States and Great Britain. House of Representatives Document No. 15 (Vol. II. Executive Documents), $28^{\text {th }}$ Congress, $1^{\text {st }}$ Session, Read on Dec. 16, 1843. [Reprinted New York: Burt Franklin, 1971].

Enders, W. 1995. Applied Econometric Time Series. New York: John Wiley.

Ernst, J. E. 1973. Money and Politics in America, 1755-1775. Chapel Hill, NC: University of North Carolina Press.

Fisher, I. 1912. The Purchasing Power of Money. New York: Macmillan.

Greene, J. P. and Jellison, R. M. 1961. 'The currency act of 1764 in imperial-colonial relations, 1764-1776. The William and Mary Quarterly 18, 485-518.

Grubb, F. 2014. A new approach to solving the colonial monetary puzzle: evidence from New Jersey, 1709-1775. National Bureau of Economic Research Working Paper 19903.

Grubb, F. 2015. Colonial Virginia’s paper money regime, 1755-1774: a forensic accounting reconstruction of the data. National Bureau of Economic Research Working Paper 21785.

Grubb, F. 2016. Is paper money just paper money? Experimentation and variation in the paper monies issued by the American colonies from 1690 to 1775. Research in Economic History, forthcoming.

Hammond, B. 1991. Banks and Politics in America. Princeton, NJ: Princeton University Press [original 1957].

Hening, W. W. (ed.) 1969. The Statutes at Large; being a Collection of all the Laws of Virginia from the First Session of the Legislature, in the Year 1619, Vols. 6-9. Charlottesville, VA: University Press of Virginia [original: Richmond, VA: Franklin Press, 1819-1821].

Homer, S. and Sylla, R. 1991. A History of Interest Rates. New Brunswick, NJ: Rutgers University Press, third edition.

Hutchinson, W. T. and Rachal, W. M. E. (eds.) 1962. The Papers of James Madison, Vol. 1. 
Chicago: University of Chicago Press.

Journal of the Commissioners for Trade and Plantations from January 1759 to December 1763:

Preserved in the Public Records Office. 1970. Nendeln, Liechtenstein: Kraus-Thomson

(original: 1935. London: Her Britannic Majesty's Stationery Office).

Journals of the Continental Congress, 1774-1789, Vols. 1-34. 1904-1937. Washington

D.C.: Government Printing Office.

Kennedy, J. P. (ed.) 1905 Journals of the House of Burgesses of Virginia, 1773-1776.

Richmond, VA: Virginia State Library.

Kennedy, J. P. (ed.) 1906a Journals of the House of Burgesses of Virginia, 1766-1769.

Richmond, VA: The Colonial Press, Everett Waddey Company.

Kennedy, J. P. (ed.) 1906b. Journals of the House of Burgesses of Virginia, 1770-1772. Richmond, VA: The Colonial Press, Everett Waddey Company.

Kennedy, J. P. (ed.) 1907. Journals of the House of Burgesses of Virginia, 1761-1765. Richmond, VA: The Colonial Press, Everett Waddey Company.

Keynes, J. M. 1936. The General Theory of Employment, Interest, and Money. New York: Houghton Mifflin Harcourt, 1991 edition.

Labaree, L. W. (ed.) 1959-1970. The Papers of Benjamin Franklin, Vols. 1-14. New Haven, CT: Yale University Press.

Lee, R. H. 1825. The Memoir of the Life of Richard Henry Lee and His Correspondence, Vol. 1. Philadelphia: H. C. Carey and I. Lee.

Mark, N. C. 2001. International Macroeconomics and Finance: Theory and Econometric Methods. Malden, MA: Blackwell.

Mays, D. J. 1952. Edmund Pendleton, 1721-1803: A Biography, Vol. 1. Cambridge, MA: Harvard University Press.

McCusker, J. J. 1978. Money and Exchange in Europe and America, 1600-1775. Chapel Hill, NC: University of North Carolina Press.

McIlwaine, H. R. (ed.) 1908. Journals of the House of Burgesses of Virginia, 1758-1761. Richmond, VA: The Colonial Press, Everett Waddey Company.

Mcllwaine, H. R. (ed.) 1909. Journals of the House of Burgesses of Virginia, 1752-1755, 1756-1758. Richmond, VA: The Colonial Press, Everett Waddey Company.

Nettels, C. P. 1934. The Money Supply of the American Colonies before 1720. Madison, WI: University of Wisconsin Press.

Newman, E. P. 2008. The Early Paper Money of America. Iola, WI: Krause Publications, (5 ${ }^{\text {th }}$ edition).

Ricord, F. W., ed. 1892. Documents Relating to the Colonial History of the State of New Jersey, Vol. 17. Trenton, NJ: John L. Murphy.

Scott, K. 1957. Counterfeiting in Colonial America. Philadelphia: University of Pennsylvania Press.

Smith, A. 1937. The Wealth of Nations. New York: Modern Library.

Smith, P. H. 1976-1994. Letters of Delegates to Congress, 1774-1789, Vols. 1-21. Washington, DC: Library of Congress.

Tillson, A. H. Jr. 2010. Accommodating Revolutions: Virginia's Northern Neck on an Era of Transformations, 1760-1810. Charlottesville, VA: University of Virginia Press.

West, R. C. 1978. Money in the colonial American economy. Economic Inquiry 16, 1-15.

William and Mary College Quarterly Historical Magazine (Apr. 1912), v. 20, no. 4, pp. 227-262. 
Appendix Table A1 Data Used in the Figure and Regressions

\begin{tabular}{lrrrrrrrrrrrr}
\hline & & & & & & & & & & & & \\
Year & MEV & APV5 & APV5 $^{\text {a }}$ & APV6 & APV6 $^{\mathrm{a}}$ & APV7 & APV7 & M & r* & Tob & P & Pop \\
& & & & & & & & & & & & \\
\hline 1755 & 89.77 & 91.47 & & 90.17 & & 88.65 & & 37,179 & 6.3 & 100.0 & 100.0 & 164,369 \\
1756 & 90.42 & 90.11 & & 88.25 & & 86.44 & & 95,583 & 4.8 & 105.9 & 98.8 & 171,326 \\
1757 & 83.13 & 86.15 & & 83.65 & & 81.23 & & 167,605 & 6.1 & 117.6 & 109.6 & 178,284 \\
1758 & 84.21 & 82.28 & 83.27 & 79.43 & 80.40 & 76.76 & 77.80 & 223,318 & 4.4 & 129.9 & 118.1 & 185,241 \\
1759 & 82.97 & 78.77 & 81.95 & 75.35 & 78.89 & 72.13 & 75.96 & 266,949 & 3.9 & 105.3 & 103.6 & 192,199 \\
1760 & 82.12 & 76.93 & 81.73 & 73.29 & 79.17 & 69.89 & 76.73 & 296,266 & 3.7 & 117.6 & 114.5 & 199,156 \\
1761 & 80.81 & 78.20 & 83.86 & 74.67 & 81.05 & 71.40 & 78.36 & 273,507 & 4.3 & 116.6 & 113.3 & 205,182 \\
1762 & 76.21 & 78.21 & 85.23 & 74.72 & 82.66 & 71.42 & 80.16 & 265,286 & 5.6 & 117.6 & 118.1 & 211,207 \\
1763 & 72.64 & 79.21 & 87.44 & 75.77 & 85.18 & 72.57 & 83.02 & 253,120 & 7.0 & 129.9 & 126.5 & 217,233 \\
1764 & 72.26 & 81.11 & 90.58 & 77.94 & 88.85 & 74.95 & 87.18 & 229,322 & 8.0 & 88.2 & 94.0 & 223,258 \\
1765 & 72.42 & 82.92 & 94.03 & 79.98 & 92.93 & 77.20 & 91.85 & 212,373 & 8.8 & 107.0 & 109.6 & 229,284 \\
1766 & 90.40 & 85.72 & & 83.23 & & 80.84 & & 193,225 & 3.2 & 128.3 & 124.1 & 235,309 \\
1767 & 92.51 & 88.57 & & 86.56 & & 84.59 & & 167,474 & 3.2 & 101.6 & 102.4 & 241,335 \\
1768 & 92.92 & 89.56 & & 87.68 & & 85.85 & & 141,723 & 3.3 & 133.2 & 127.7 & 247,360 \\
1769 & 95.22 & 89.49 & & 88.03 & & 86.24 & & 130,677 & 2.3 & 111.8 & 112.0 & 253,386 \\
1770 & 98.42 & 91.51 & & 89.93 & & 88.38 & & 120,136 & 0.9 & 149.7 & 141.0 & 259,411 \\
1771 & 93.96 & 92.14 & & 90.69 & & 89.27 & & 139,192 & 3.8 & 131.6 & 127.7 & 265,212 \\
1772 & 93.97 & 92.36 & & 91.00 & & 89.68 & & 102,630 & 3.9 & 131.0 & 131.3 & 271,013 \\
1773 & 89.51 & 91.55 & & 90.10 & & 88.70 & & 66,068 & 6.4 & 95.7 & 100.0 & 276,814 \\
1774 & 89.13 & 88.04 & & 86.06 & & 84.116 & & 42,713 & 4.5 & 126.7 & 124.1 & 282,615 \\
& & & & & & & & & & & & \\
\hline
\end{tabular}

Sources: See text; Table 2; Carter, et al (2006, v. 5, pp. 652, 682-7); Grubb (2015).

Notes: See text for definitions and construction. $\mathrm{M}$ is in $£_{\mathrm{VA}}$ (Virginia pounds). The number after APV refers to the risk-free time-discount rate used. Pop is only the white population, with linear interpolated values between decadal benchmarks. "Tob" is the average for York and Rappahannock River Basins tobacco prices with $1755=100$. The raw price is 1.87 in 1755. P is a price index using "Tob" plus York River corn and James River wheat prices with $1755=100$. The raw average price for 1755 is 0.83 .

${ }^{\mathrm{a}}$ Counterfactual APV with no suspected treasurer malfeasance revealed until 1766. The other APV columns assume perfect foresight regarding treasurer diversion of redemption funds. 